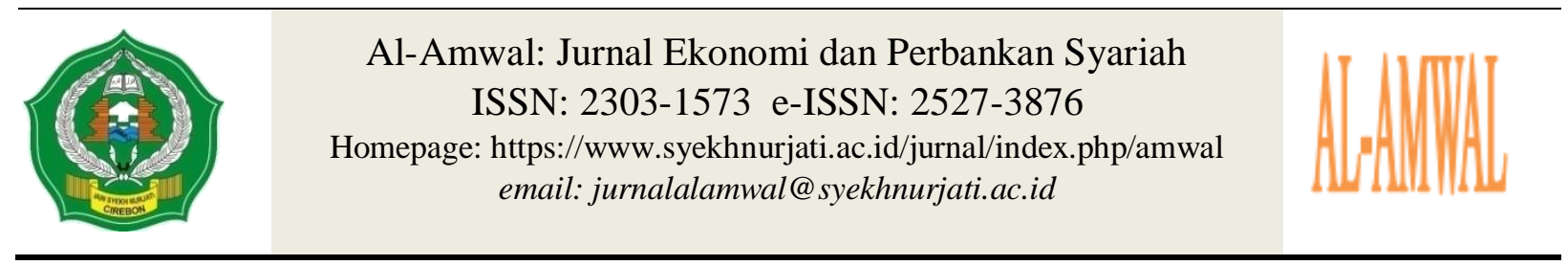

\title{
LITERATION AND FINANCIAL INCLUSION AMONG CREATIVE ECONOMIC MSMES; A COMPARATIVE STUDY
}

\author{
Layaman \\ Ekonomi Syariah, IAIN Syekh Nurjati Cirebon, Cirebon \\ E-mail:layaman72@gmail.com \\ Robbani \\ Perbankan Syariah, IAIN Syekh Nurjati Cirebon, Cirebon \\ E-mail: robban@syekhnurjati.ac.id \\ Fella Hafidza \\ Perbankan Syariah, IAIN Syekh Nurjati Cirebon, Cirebon, \\ E-mail: fellahafidza12@gmail.com
}

\begin{abstract}
Micro, Small and Medium Enterprises are considered as sectors that are able to survive in the face of the economic crisis shock. However, there are some problems in running this Micro and Small and Medium Enterprises. This research is motivated by problems that hamper this development including limited management of financial management, human resources and access to capital. This is thought to have occurred because of low financial literacy among Small and Medium Enterprises. Therefore, this study aims to determine the condition and compare financial literacy and inclusion that is believed to help in the business development of the Creative Culinary Subsector of Micro Small and Medium Enterprises in the City of Cirebon with Cirebon Regency.

The population in this study was 24,861 Micro Small and Medium Enterprises and 100 respondents. The sampling technique used purposive sampling with a sample size of 200 respondents or around 100 respondents in Cirebon City and 100 respondents in Cirebon Regency. While the analysis technique in this study uses multiple linear regression analysis with the help of SPSS Version 2.1

The results of this study that the variable Literacy and Financial Inclusion significantly influence the Development of Culinary Subsectors of the Creative Economy of Small and Medium Enterprises in the City and District of Cirebon. The comparative value is that the condition of Financial Literacy or Inclusion in the Cirebon City is greater than in Cirebon Regency.
\end{abstract}

Keywords: Financial Literacy, Financial Inclusion, Micro, Small and Medium Enterprises 


\begin{abstract}
Abstrak
Usaha Mikro Kecil dan Menengah dinilai sebagai sektor yang mampu bertahan menghadapi guncangan krisis ekonomi. Namun ada beberapa kendala dalam menjalankan UMKM ini. Penelitian ini dilatarbelakangi oleh permasalahan yang menjadi penghambat perkembangan tersebut antara lain keterbatasan pengelolaan keuangan, sumber daya manusia dan akses pemodalan. Hal ini diduga terjadi karena rendahnya literasi keuangan di kalangan Usaha Kecil dan Menengah. Oleh karena itu, penelitian ini bertujuan untuk mengetahui kondisi dan membandingkan literasi dan inklusi keuangan yang diyakini dapat membantu dalam pengembangan usaha Subsektor Kuliner Kreatif Usaha Mikro Kecil dan Menengah di Kota dan Kabupaten Cirebon.

Populasi dalam penelitian ini adalah 24.861 UMKM dan 100 responden. Teknik pengambilan sampel menggunakan purposive sampling dengan jumlah sampel 200 responden atau sekitar 100 responden di Kota Cirebon dan 100 responden di Kabupaten Cirebon. Sedangkan teknik analisis dalam penelitian ini menggunakan analisis regresi linier berganda dengan bantuan SPSS Versi 2.1

Hasil penelitian ini bahwa variabel Literasi dan Inklusi Keuangan berpengaruh signifikan terhadap Perkembangan Subsektor Kuliner pada Ekonomi Kreatif Usaha Kecil dan Menengah di Kota dan Kabupaten Cirebon. Nilai komparatifnya adalah kondisi Literasi atau Inklusi Keuangan di Kota Cirebon lebih besar daripada di Kabupaten Cirebon.
\end{abstract}

Kata Kunci: Literasi Keuangan, Inklusi Keuangan, Usaha Mikro, Kecil dan Menengah

\title{
INTRODUCTION
}

The economic condition expected by Indonesia is a sustainable economy and also has several sectors as pillars and support for economic activity in Indonesia. Sustainability is meant by the ability to adapt to geographic conditions and new economic challenges, which in turn result in sustainable growth. High growth is reflected in the competence of individuals in creating innovation (Aldy Purnomo, 2016).

One of the real sectors that deserves to be a priority is the creative economy. In contrast to other sectors that are highly dependent on the exploitation of natural resources, the power of the creative economy relies more on the advantages of human resources. The synergy between the creative economy and MSMEs is a development model for increasing sales of products and services that are potential enough to be developed by carrying out additional creative activities to develop MSMEs in Indonesia.

Culinary is one of the sub-sectors of the creative economy which contributes significantly to the income of the tourism sector and the creative economy. This culliner industry has great potential to develop, in 2019 the Food and Beverage industry contributes $6.35 \%$ to National GDP (Rihanto, 2019). Therefore, it will continue to support this sub-sector to make it more advanced. The culinary sub-sector's creative economy MSMEs are also among the businesses that are most in demand by MSME players today.

Therefore, the performance and growth of Small and Medium Enterprises (SMEs) throughout the archipelago has become the center of great attention of development economists, entrepreneurs, governments, venture capital companies, financial institutions and non-governmental organizations (Eniola \& Entebang, 2014). 
The main problem in running Micro, Small and Medium Enterprises (MSMEs) is not limited to financial management and limited resources, but also access to capital owned by business actors. Olawale \& Garwe (2010) call it a key factor that inhibits the growth of micro, small and medium enterprises (MSMEs). The low level of financial literacy among MSME actors is one of the causes of the lack of access to financial institutions for this sector. MSME players tend to lack understanding of financial products offered by other financial institutions (Valenta Sari, 2016).

Financial literacy, in the new business reality, is the ability to oversee financial resources during the business life cycle and connect with financial products and services. Financial literacy is about managing and how to make effective decisions about the use of financial management (Gavigan, 2010). This has become one of the important strategic tools in managing the allocation of substantial financial resources and financial strength.

Indeed, for companies, finance is an important aspect of company operations. Without adequate financial access, the company's health is likely to weaken and its growth potential is threatened (Adomako, S., Danso, A., \& Ofori Damoah, J., 2016). Therefore, experts conclude that the relationship between access to finance and company growth can be considered positive (Cooper, Gimeno-Gascon, and Woo 1994; R Understanding 2011; Storey 1994). The main principle is that companies with strong financial strength outperform other companies.

However, high access to credit does not always guarantee high sales growth from these companies. One must also look at financial inclusion (access to credit) related to company growth. Besides that, financial inclusion plays an important role in increasing the growth of a company. Previous empirical studies concluded that there is a positive relationship between financial inclusion and company growth (Efobi et al. 2016; Nizam, R., et al, 2020).

Research on comparisons of financial literacy and inclusion between the two regions is rare. This study aims to examine the level of literacy and financial inclusion between the City and Regency of Cirebon.

\section{LITERATURE REVIEW}

\section{Financial Literacy}

Financial literacy is knowledge and skills in making decisions effectively in a financial context, both individually and in groups who have an understanding of concepts and risks. Based on the framework of the Organization for Coorperation and Development, to measure financial literacy in various countries around the world there are three main variables, namely Financial Knowledge, Financial Behavior, and Financial Attitude.

Financial Knowledge is education on how to manage personal finances to face a future with economic independence. Financial knowledge includes general knowledge of personal finance, savings and loans, insurance, and investments. Financial behavior according to Irene Herdjiono and Lady Angela Damanik (2016) is a person's ability to manage planning, budgeting, checking, managing, controlling, searching and storing daily financial funds. Meanwhile, Financial Attitudes are a state of mind, opinion and judgment about finances.

Financial literacy is related to one's competence to manage finances. Financial literacy is defined as the knowledge and understanding of the concepts of finance, ability, motivation and trust in applying some knowledge and orderly understanding in 
making effective decisions within the scope of financial contexts to improve the financial wellbeing of individuals and individuals and enable them to participate in economic life (Slamet, Yulianto, Ridloah, \& Abiprayu, 2019)

Several previous studies have measured and analyzed financial literacy and financial inclusion on the development of MSMEs. Among these studies are:

Yushita, A. N. (2017) who conducted a study entitled "The Importance of Financial Literacy for Personal Financial Management". This study broadly concludes that financial literacy will have a positive effect on financial inclusion which will have an impact on the development of MSMEs.

Meanwhile, the research conducted by Dwitya Aribawa (2016) entitled "The Effect of Financial Literacy on the Performance and Sustainability of MSMEs in Central Java". This research broadly concludes that if entrepreneurs in the creative industry MSME sector have adequate literacy skills, the business and financial decisions that will be made will lead to good development from time to time, increase the ability of businesses to survive in the midst of a crisis and ultimately. make the business long-term sustainability.

Idawati \& Pratama (2020) researched 100 MSMEs in Denpasar City using structural equation analysis techniques based on partial least square, the results showed that there was a significant influence between financial literacy on the performance and sustainability of MSMEs.

Resmi (2019) researched Creative MSMEs in Yogyakarta because Yogyakarta has a variety of traditions and cultures with a skilled, innovative and creative population that accelerates the growth of Creative MSMEs. Using the correlation test, it is found that tax literacy, performance, and business growth have a significant linear relationship. Meanwhile, tax literacy and competitive advantage do not have a significant linear relationship. Financial literacy, performance, business growth, and competitive advantage are insignificant linear relationships. The theoretical implication, this study provides additional knowledge about the importance of the relationship pattern of financial literacy, tax literacy, performance, business growth, and competitive advantage for Creative MSMEs.

Ermawati (2019), Success in managing cooperative finances is strongly influenced by personal behavior in the cooperative management, knowledge or understanding of management, lifestyle and financial goals (short, medium and longterm goals of the family). This research finding is financial literacy influences financial performance through the conformity of financial management behavior in civil servant cooperatives in Bandar Lampung. Based on a review of the previous literature, the hypothesis that can be developed is:

$\mathrm{H}_{1}=$ Financial literacy affects the growth of the Creative Economy MSMEs in the Culinary Subsector.

\section{Financial Inclusion}

Financial Inclusion is defined as an effort to reduce all forms of price and non-price barriers to public access to the use of financial services. The Financial Inclusion Index (IKI) is an alternative way of measuring financial inclusion using a multidimensional index based on macroeconomic data, especially on the coverage of banking sector services. The measurement of IKI is basically an effort made by Bank Indonesia to combine various indicators of the banking sector, so that in the end IKI can combine various information regarding the dimensions of an inclusive financial system, namely 
access, usage, and quality. of banking services. The following is a description of the three dimensions, namely Access, Usage, and Quality.

The access dimension is a dimension used to measure the ability to use formal financial services, so that potential barriers to opening and using bank accounts can be seen, such as costs or physical affordability of financial services (bank offices, ATMs, etc.). The Usage Dimension is a dimension used to measure the ability to actually use financial products and services, including in terms of regularity, frequency and duration of use. Meanwhile, quality is a dimension used to determine whether the availability of attributes of financial products and services has met customer needs.

The goal of the financial inclusion program is the availability of financial services for all segments of society, with special attention to the poor, productive poor people, migrant workers, and residents in remote areas (Slamet et al., 2019).

Fitriana, W., Rustiadi, E., Fauzi, A., \& Anggraeni, L. (2018) in a study entitled "Strengthening Financial Inclusion in Small-Scale Creative Industries in West Sumatra" which obtained research results that financial inclusion in the industry creativity in West Sumatra is still low, while the low level of financial inclusion in financial services among business actors will affect the development of the creative industry in West Sumatra.

Sanistasya, PA, Rahardjo, K., \& Iqbal, M. (2019) also conducted research on financial inclusion entitled "The Effect of Financial Literacy and Financial Inclusion on Small Business Performance in East Kalimantan" which concluded that financial inclusion variables had a positive influence direct and significant to the business performance variable. Based on 4 indicators, namely Access, Quality, Usage, Welfare, small business actors will respond to feel the urge for financial inclusion variables. This positive influence is because small business actors in the entrepreneurship education and training group have been given programs and interventions that also involve financial skills and competencies to support financial inclusion of small business actors. Lakuma, Marty, \& Muhumuza (2019) examined MSMEs in Uganda, the results of their research also showed that financial literacy affects the growth of MSMEs. Based on a review of the previous literature, the hypothesis that can be developed is:

$\mathrm{H}_{2}=$ Financial inclusion affects the growth of the Creative Economy MSMEs in the Culinary Subsector.

\section{Micro, Small and Medium Enterprises (MSMEs) Creative Economy, Culinary Subsector}

Micro, Small and Medium Enterprises or MSMEs is a general term in the realm of economics which refers to productive economic enterprises owned by individuals or business entities in accordance with the criteria stipulated by Law No. 20 of 2008. MSMEs are important job generators (Lakuma, Marty, \& Muhumuza, 2019). Creative economy as a new economic concept relies on the idea of creativity, culture and technology which is believed to be able to become a source of new growth for the national economy going forward. One of the creative economy MSME sub-sectors that has contributed significantly to state income is culinary.

Based on the results of statistics and surveys conducted by Bekraf and BPS in 2015, it was found that culinary was one of the three leading sub-sectors along with fashion and crafts among other sub-sectors included in the creative economy category in Indonesia. Therefore, this culinary sub-sector is often encountered with creative innovations that will attract consumers. In this study the dimensions used to measure the development of MSMEs are finance, marketing and Human Resources (HR). 


\section{METHOD}

The population in this study were the creative economy SMEs in the culinary subsector in Cirebon City and Regency. The population of MSMEs in the city of Cirebon is 2,552 and in Cirebon Regency is 22,309. Samples were taken using purposive sampling technique. By using the Slovin formula, a sample of 100 MSMEs was obtained. Therefore, the sample taken in the City is 100 MSMEs and in the Regency 100 MSMEs. While the analysis technique used is multiple linear regression.

\section{RESULT AND DISCUSSION}

\section{General description of respondents}

Based on the latest education, respondents in this study can be seen in the table below:

Table 1. Characteristics of Respondents Based on Latest Education

\begin{tabular}{|c|c|c|c|c|c|c|}
\hline \multirow[t]{2}{*}{ Education } & \multicolumn{2}{|c|}{ City } & \multicolumn{2}{|c|}{ Regency } & \multicolumn{2}{|c|}{ Amount } \\
\hline & $\mathbf{F}$ & $\%$ & $\mathbf{F}$ & $\%$ & $\mathbf{F}$ & $\%$ \\
\hline SMP/MTS & 15 & 15,0 & 17 & 17,0 & 32 & 16,0 \\
\hline SMA/SMK/MA & 62 & 62,0 & 71 & 71,0 & 133 & 66,5 \\
\hline Diploma/Sarjana & 23 & 23,0 & 12 & 12,0 & 35 & 17,5 \\
\hline Total & 100 & 100,0 & 100 & 100,0 & 200 & 100,0 \\
\hline
\end{tabular}

(Source: Primary Data, processed in 2020)

In the table above, regarding the characteristics of respondents based on the latest education in the City and Regency of Cirebon, it can be seen that the largest number of respondents are respondents who have SMA/SMK/MA education, as many as 133 respondents or $66.5 \%$. This is because the number of MSMEs who only graduate from SMA/SMK/MA is more ready to open their own business without applying for jobs elsewhere on the grounds of obstacles in SMA/SMK/MA Certificate.

In this study, the characteristics of respondents based on ownership of bank accounts are as follows:

Table 2. Characteristics of Respondents Based on Ownership of Bank Accounts

\begin{tabular}{|crrrrrr|}
\hline $\begin{array}{c}\text { Ownership of Bank } \\
\text { Accounts }\end{array}$ & \multicolumn{2}{c}{ City } & \multicolumn{2}{c}{ Regency } & \multicolumn{2}{c|}{ Amount } \\
\cline { 2 - 7 } & F & $\%$ & F & $\%$ & F & $\%$ \\
Yes & 62 & 62,0 & 55 & 55,0 & 117 & 58,5 \\
No & 38 & 38,0 & 45 & 45,0 & 83 & 41,5 \\
Amount & 100 & 100,0 & 100 & 100,0 & 200 & 100,0 \\
\hline
\end{tabular}

(Source: Primary Data, processed in 2020)

In the table above, it can be seen that the ownership of bank accounts in Cirebon City and Regency of 200 respondents is around 117 people or $58.5 \%$ who already have bank accounts, both conventional and Sharia. It can be seen that more and more people have started to become aware of banking that is able to help run their business both during buying and selling transactions and capital.

Associated with the main variable in the study, consisting of question items arranged in a questionnaire concerning attitudes. Research on financial literacy is divided into 3, namely Financial Knowledge, Financial Behavior (Financial Behavior, Financial Attitude). The results of descriptive data processing obtained a description of financial literacy in Cirebon City shows that the largest average is 4,38 , namely Financial Behavior with the indicator "Saving and Investment" due to one's awareness of one's future behavior, where a person will not know what will happen in the future, 
the money originating from business income will not be fully used for consumption but rather stored to pay unexpected events at a later date.

Meanwhile, financial literacy in Cirebon Regency shows that the largest average is 4.63, namely Financial Attitude with the indicator "Obsession" due to a person's mindset and perception of the future to manage finances well. This attitude of comparing prices is a natural attitude where someone feels that the difference in price for something even if a little is very valuable.

Research on financial inclusion is divided into 3, namely Access, Usage, and Quality. The results of descriptive data processing obtained an overview of financial inclusion in the City and Regency of Cirebon, showing that the largest average was 4.33 and 4.71, namely "Use of Bank Accounts". This value indicates that the ability of business actors to use bank accounts is more often due to easier access and trust in banks in conducting financial transactions.

Research on financial inclusion is divided into 3, including finance, marketing, and human resources. The results of descriptive data processing obtained an overview of the development of MSMEs in the City and Regency of Cirebon, namely Human Resources (HR) with the indicator "Number of Employees and Employee Welfare" having the largest average of 4.38 and the indicator "Number and Employee Skills" of 4, 75 indicates that the culinary MSMEs located in Cirebon City and Regency are growing. The number of employees and the increasing welfare and skills of employees shows that the business is getting bigger.

\section{Hypothesis testing}

Before this test is carried out, first the classical regression assumption test, normality, heteroscedasticity, multicollinearity and linearity are tested. Based on the results of data processing, it is known that this regression model has passed the classical regression assumption test.

\section{Multiple Linear Regression Analysis}

Multiple regression was used to test the hypothesis. The following is the result of statistical data processing that describes the relationship between Financial Literacy (X1) and Financial Inclusion (X2) variables on the Growth of MSME (Y)

Table 3. Multiple Linear Regression Test Table

\begin{tabular}{|lllll|}
\hline Model & City & Sig. & Regency & Sig. \\
\cline { 2 - 5 } & Standardized Coefficients & & $\begin{array}{l}\text { Standardized } \\
\text { Coefficients } \\
\text { Beta }\end{array}$ & \\
Financial Literacy & 0,249 & & 0,179 & 0,084 \\
Financial Inclusion & 0,492 & 0,070 & 0,401 & 0,000 \\
$\begin{array}{l}\text { Multiple } \\
\text { regression }\end{array}$ & $\mathrm{Y}=0,416 \mathrm{X}_{1}+0,349 \mathrm{X}_{2}$ & & $\mathrm{Y}=0,341 \mathrm{X}_{1}+0,283 \mathrm{X}_{2}$ & \\
Adjusted R Square & 0.427 & & & \\
\hline
\end{tabular}

(Source: Primary Data, processed in 2020)

The Influence of Financial Literacy on the Growth of MSMEs in the Culinary Subsector in City and Cirebon Regency

There is a positive effect of Financial Literacy on the Growth of Creative Economy MSMEs in the Culinary Subsector in the City and Cirebon Regency. For literacy in the Cirebon Regency has a weak influence. 
In this Financial Literacy variable, the indicator that has the largest average value in Cirebon City is "Saving and Investment", which is 4.38. This is because someone's behavior is aware of the future, where a person will not know what will happen in the future, the money from business income will not be fully used for consumption but rather saved to pay for unexpected events at a later date. While the largest average value in Cirebon Regency is "Obsession" of 4.63. This is because a person's mindset and perception of the future to manage finances properly.

Even though there is the lowest value in this variable, namely "Weakness" of 3.14 and "Credit Management" of 3.14. However, this result is still in the high level of literacy category. This can be due to the high average value of other indicators.

The results of this study are the same as the research by Dwitya Aribawa (2016); Adomako, S., Danso, A., \& Ofori Damoah, J. (2016) that financial literacy affects the performance and business of creative MSMEs which are expected to be able to make the right management and financial decisions to improve performance.

Justin (2010) revealed that someone who has good financial literacy plus with behavior in managing finances appropriately, can be said as prosperous in financial terms. Thus, to be prosperous, financial literacy must lead to good financial management behavior for someone because with good skills in managing finances, it will avoid a financial problem. In the context of cooperatives, financial performance will be achieved maximally if these conditions can be met.

The value of Standardized Coefficients Beta for City Financial Literacy is 0.249 and Regency is 0.179 , it means that the value of Financial Literacy in Cirebon City is greater than Cirebon Regency, which is 0.249 greater than 0.179 . From these data it can be concluded that Financial Literacy in the City area is higher than in the Regency area.

\section{The Influence of Financial Inclusion on the Growth of MSMEs in the Culinary Subsector in Cirebon City and Regency}

There is a positive influence of Financial Inclusion on the Growth of Creative Economy MSMEs in the Culinary Subsector in the City and Regency of Cirebon. In the Financial Inclusion variable, the indicator that has the largest average value in Cirebon City is "Use of Bank Accounts", which is 4.33. This value indicates that the ability of business actors to use bank accounts is more often due to easier access and trust in banks in conducting financial transactions. Meanwhile, in Cirebon Regency, the highest average score was "Use of Bank Accounts", is 4.71. This value indicates that the ability of business actors to use bank accounts is more often due to easier access and trust in banks in conducting financial transactions.

Although there is the lowest value in this variable, is the indicator "Use of Banking Cards" which is 3.37 for Cirebon City and the indicator "Ease of use of Mobile Banking applications" is 2.64 in Cirebon Regency. However, this result is still in the high level of literacy category. This can be due to the high average value of other indicators.

The results of this study are supported by Poppy Alvianolita, Kusdi Rahardjo, and Mohammad Iqbal (2019) who concluded that financial inclusion variables have a direct and significant positive effect on business performance variables.

The value of Standardized Coefficients Beta for Financial Inclusion in the City is 0.492 and Regency is 0.401 , it means that the value of Financial Inclusion in Cirebon City is greater than Cirebon Regency which is 0.492 greater than 0.401 . From these data 
it can be concluded that the influence of the Financial Inclusion variable in the City area has a greater positive effect on the development of MSMEs than in the Regency area.

The coefficient of determination for the City area is $43.82 \%$ and the Regency is $26.94 \%$. This shows that the influence of literacy and financial inclusion variables on the development of MSMEs in Cirebon City is greater than that of the Regency with a difference of $16.88 \%$.

\section{CONCLUSION}

The results of this research can be shown as follows: Financial Literacy has a significant effect on the Growth of Creative Economy MSMEs in the Culinary Subsector in Cirebon City and Regency; Financial Inclusion has a significant effect on the Growth of Creative Economy MSMEs in the Culinary Subsector in Cirebon City and Regency.

The comparison between the Creative Economy SMEs in the Culinary Subsector in the City and Regency of Cirebon can be set aside as follows: Financial Literacy in the City area has a greater positive influence on the Growth of MSMEs compared to the Cirebon Regency area; The influence of Financial Inclusion in the City area has a greater positive effect on the Growth of MSMEs in Cirebon Regency.

The results of this study have several consequences:

First, based on the smallest average Financial Literacy variable, which is the low ability to utilize credit financing so as not to go bankrupt, one of which can be overcome by providing education to customers regarding credit, such as financial services used, loan options, and investment diversification. This will increase the basic understanding of business owners to calculate or estimate changes that will impact their business and be able to better manage their finances.

Second, based on the smallest average Financial Inclusion variable, the low level of use of banking transaction support products such as mobile banking applications can be overcome by holding a program for banks to help their customers install the Mobile Banking application as well as providing education about ease in the transaction process and unnecessary worrying about safety concerns when carrying cash.

Third, the smallest average MSMEs Growth variable is the low level of public perception of business capital from eligible party financing, which can be improved by communicating with the public regarding capital financing from other parties that will help to develop the business without worrying about unwanted credit risks while know the credit or loan chosen and be able to manage finances well. Meanwhile, the limitations in joining a startup company can be overcome by promoting products through the internet to expand the marketing network.

\section{REFERENCES}

Aldy Purnomo, R. (2016). Ekonomi Kreatif Pilar Pembangunan Indonesia. Surakarta: Ziyad Visi Media.

Adomako, S., Danso, A., \& Ofori Damoah, J. (2016). The moderating influence of financial literacy on the relationship between access to finance and firm growth in Ghana. Venture Capital, 18(1), 43-61.

Cooper, A. C., F. J. Gimeno-Gascon, and C. Y. Woo. 1994. "Initial Human and Financial Capital as Predictors of new Venture Performance." Journal of Business Venturing 9 (5): 371-395.

Ermawati, L. (2019). The Effect Of Financial Literation On Financial Performance In 
Cooperatives Of State Employees In Bandar Lampung. Finansia: Jurnal Akuntansi Dan Perbankan Syariah, 2(1), 69-83. JOUR.

Efobi, Uchenna Rapuluchukwu, Voufo Belmondo Tanankem, and Ibukun Beecroft. 2016. Incentives and Firms'Productivity: Exploring Multidimensional Fiscal Incentives in a Developing Country.World Development Perspectives 5: 56-59

Eniola, A. A., \& Entebang, H. (2014). SME firms performance in Nigeria: Competitive advantage and its impact. International Journal of Research Studies in Management, 3(2), 75-86. http://dx.doi.org/10.5861/ijrsm.2014.854

Fitriana, W., Rustiadi, E., Fauzi, A., \& Anggraeni, L. (2018). Penguatan Inklusi Keuangan pada Industri Kreatif Berskala Mikro Kecil di Sumatra Barat. Jurnal Ekonomi dan Pembangunan Indonesia, 140-153.

Gavigan, K. (2010). Show me the money resources: Financial literacy for 21 st century learners (pp. 28(25):24-27.): Library Media Connection.

Herdjiono, I., \& Damanik, L. A. (2016). Pengaruh financial attitude, financial knowledge, parental income terhadap financial management behavior. Jurnal Manajemen Teori dan Terapan| Journal of Theory and Applied Management, 9(3).

Idawati, I. A. A., \& Pratama, I. G. S. (2020). Pengaruh Literasi Keuangan Terhadap Kinerja dan Keberlangsungan UMKM di Kota Denpasar. Warmadewa Management and Business Journal (WMBJ), 2(1), 1-9. JOUR.

Lakuma, C. P., Marty, R., \& Muhumuza, F. (2019). Financial inclusion and micro, small, and medium enterprises (MSMEs) growth in Uganda. Journal of Innovation and Entrepreneurship, 8(1), 15. JOUR. http://doi.org/10.1186/s13731-019-0110-2

Nizam, R., Abdul Karim, Z., Sarmidi, T., \& Abdul Rahman, A. (2020). Financial Inclusion and Firms Growth in Manufacturing Sector: A Threshold Regression Analysis in Selected Asean Countries. Economies, 8(4), 80.

Olawale, F., \& Garwe, D. (2010). Obstacles to the growth of new SMEs in South Africa: A principal component analysis approach. African Journal of Business Management, 4(5), 729. JOUR.

Resmi, S. (2019). Is There a Pattern of Relationships between Financial Literacy, Tax Literacy, Business Growth, and Competitive Advantage on Creative MSMEs in Yogyakarta. Journal of Advanced Management Science Vol, 7(4). JOUR.

Rihanto, D. (2019). Pertumbuhan Industri Makanan dan Minuman Sumbang 6,35\% terhadap PDB Nasional.

Sanistasya, P. A., Rahardjo, K., \& Iqbal, M. (2019). Pengaruh Literasi Keuangan dan Inklusi Keuangan Terhadap Kinerja Usaha Kecil di Kalimantan Timur. Journal Economia, 15(1), 48-59.

Slamet, A., Yulianto, A., Ridloah, S., \& Abiprayu, K. B. (2019). Financial Inclusion and Financial Literation for "Laku Pandai"Customers. KnE Social Sciences, 1-8. JOUR.

Storey, D. J. 1994. Understanding the Small Business Sector. London: Routledge.

Valenta Sari, E. (2016). BI: Tingkat Literasi Keuangan Pelaku UMKM Rendah. CNN Indonesia.

Yushita, A. N. (2017). Pentingnya literasi keuangan bagi pengelolaan keuangan pribadi. Nominal: Barometer Riset Akuntansi dan Manajemen, 6(1), 11-26. 